\title{
CTOPIHKИ ICTOPIÏ
}

УДК 574.5/.6 (477.63)(09)

DOI https://doi.org/10.32851/wba.2019.1.10

\section{ВИДАТНИЙ УКРАЇНСЬКИЙ ВЧЕНИЙ У ГАЛУЗІ ВОДНИХ БІОРЕСУРСІВ ТА АКВАКУЛЬТУРИ, ЗАСНОВНИК КОСМІЧНОЇ ГІДРОБІОЛОГІї ПРОФЕСОР Г.Б. МЕЛЬНИКОВ}

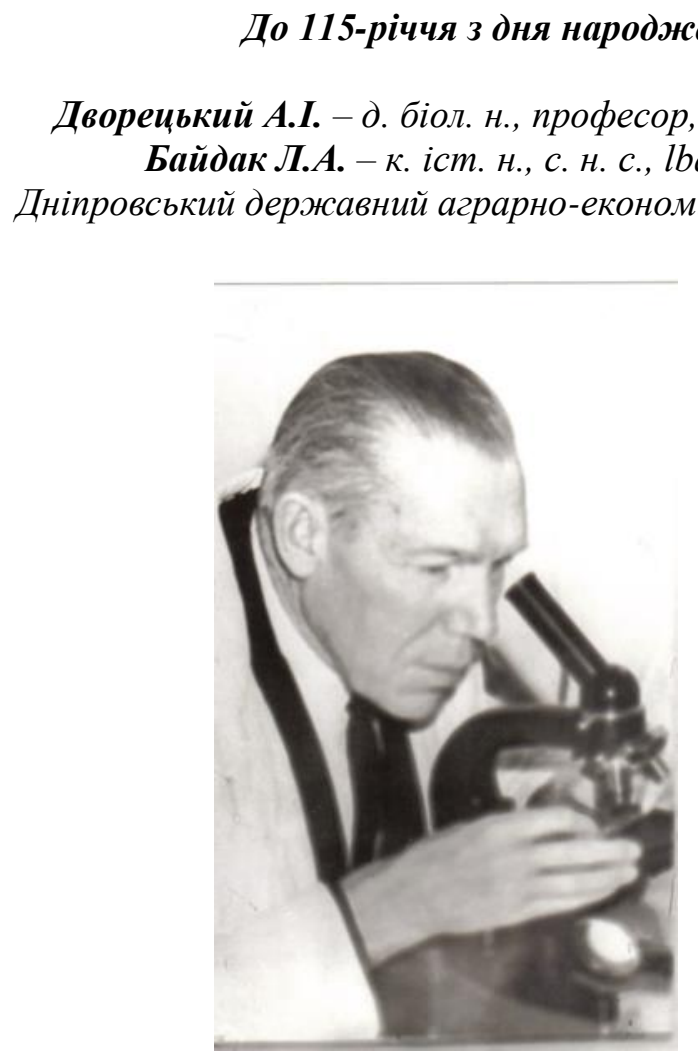

Розглянуто життя та діяльність видатного українського вченого у галузі водних біоресурсів та аквакультури проф. Г.Б.Мельникова. Відзначено внесок 
проф. Г.Б.Мельникова у формування вчення про техногенну трансформацію прісноводних екосистем. За широтою охоплення матеріалу, глибиною його опрацювання, практичною значимістю висновків роботи Г. Б. Мельникова й до теперішнього часу залишаються фундаментальною базою досліджень для фахівців-гідробіологів.

Підкреслено роль Г.Б. Мельникова, у заснуванні нового напряму гідробіологічної науки - космічної гідробіології. Уловлюючи тенденції розвитку науки у дослідженні космосу Г.Б. Мельников стає ініціатором і фактичним засновником принципово нового напрямку в гідробіологічній науці - космічної гідробіології. Як вчений-біолог професор Г. Б. Мельников, звернув свою увагу на проблему життєзабезпечення космонавтів в умовах тривалих космічних польотів (забезпечення екіпажу повітрям, водою, їжею, утилізація продуктів їх життєдіяльності), яка може бути оптимально вирішена шляхом створення замкнутої екологічної системи (ЗЕС). Під керівництвом Г.Б. Мельникова була розроблена оригінальна методика вивчення дії екстремальних космічних факторів (космічного опромінення, невагомості тощо) на поведінку риб - головного об'єкта «гетеротрофної ланки ЗЕС»; були проведені експериментальні роботи з вивчення поведінки риб в герметичних акваріумах, а також з вивчення раціонів харчування риб на основі хлорели.

Мельников Г.Б. підготував більш ніж 30 кандидатів наук, був науковим консультантом багатьох докторських дисертацій. Він нагороджений орденом Трудового Червоного Прапора, орденом «Знак Пошани», трьома медалями, удостоєний почесного звання Заслуженого діяча науки, був Почесним членом ВГБО, членом Іхтіологічної комісії СРСР, членом редколегії «Гідробіологічного журналу».

Ключові слова: гідроекологія, техногенно трансформовані прісноводні екосистеми, Дніпрогес, Дніпропетровська державна гідробіологічна станція, водосховище, зоопланктон, космічна гідробіологія, іхтіологія.

Георгій Борисович Мельников (22. 01. 1904 - 11. 05. 1973 рр.) народився в с. Чернава Орловської області в сім ї селянина-бідняка $[1$, c. $65-66 ; 3$, с. 43]. У 1925 p. розпочав навчання на робітфаці Дніпропетровського інституту народної освіти (зараз ДНУ імені О. Гончара). Після закінчення інституту в 1929 році Г.Б. Мельников був залишений в аспірантурі при Дніпропетровській гідробіологічній станції під керівництвом проф. Д.О. Свіренка, де він досліджував зоопланктон і іхтіофауну порожистої частини Дніпра, новостворенної водойми - Дніпровського водосховища та непроточних водойм степового Придніпров'я. Ще аспірантом Г.Б. Мельников почав викладати в Дніпропетровському робітничому університеті; з 1932 до 1934 pp. він працює доцентом Дніпропетровської Вищої сільськогосподарської школи. У 1930 - 1938 рр. він науковий співробітник Дніпропетровської гідробіологічної станції, з 1938 до 1940 pp. Г.Б. Мельников - директор Дніпропетровської гідробіологічної станції [1, с. 65-66; 3, с. 43]. Одночасно, з 1934 р. до 1940 р., він працював доцентом, а потім завідувачем кафедри зоології Дніпропетровського сільськогосподарського інституту. У 1936 р. Г.Б. Мельников захистив кандидатську, в 1940 р. - докторську дисертацію, в якій узагальнив дослідження змін зоопланктону Дніпра 
після створення Дніпровського водосховища. Г. Б. Мельников організовував й брав активну участь в експедиціях, що проводилися Дніпропетровською гідробіологічною станцією на порожисту ділянку Дніпра, а потім по Дніпровському водосховищу, яке стало еталоном методології й принципів вивчення впливу гідробудівництва на великих рівнинних ріках на фізико-хімічний та біологічний режим водойм.

Результати вивчення дніпропетровськими гідробіологами процесів формування Дніпровського водосховища склали повний опис фізико-хімічних та біологічних особливостей водної екосистеми колишньої порожистої частини Дніпра, трансформованої в екосистему новоствореної водойми - Дніпровського водосховища. Вивчаючи зоопланктон порожистої ділянки р. Дніпра під впливом побудови греблі Дніпрогесу Г.Б. Мельников підкреслював, що зоопланктон зазнав значних змін. У до дніпробудівській період у зоопланктоні ділянки р. Дніпро, на якій було створене Дніпровське водосховище, кількісно й якісно домінували коловертки $(97,47 \%)$, а інші групи були представлені ракоподібними: веслоногі рачки - 3,45\%, гіллястовусі 0,08\%. Щільність зоопланктерів влітку наближалася до 100 тис. особин на $1 \mathrm{~m}^{3}$ води. У порожистій частині спостерігалося деяке зменшення кількості зоопланктерів завдяки руйнівній дії порогів У перші ж роки затоплення в зоопланктоні стали з'являтися нові форми, - у зв'язку 3 чим зоопланктон став більш різноманітним у видовому відношенні. Після затоплення в зоопланктоні починають домінувати веслоногі та гіллястовусі рачки. Збільшилися кількісні показники зоопланктону влітку: від 180 тис.екз $/ \mathrm{m}^{3}$ до 391 тис.екз $/ \mathrm{m}^{3}$ у верхній частині водосховища та від 45 тис.екз $/ \mathrm{m}^{3}$ до 369 тис.екз $/ \mathrm{m}^{3}-$ у колишній порожистій частині. Г.Б. Мельников зазначав, що збільшення кількості зоопланктерів відбулось завдяки таким чинникам: 1) зростанню вмісту органічних речовин у воді та, відповідно, розвитку фітопланктону; 2) значному уповільненню течії.

За широтою охоплення матеріалу, глибиною його опрацювання, практичною значимістю висновків роботи Г.Б. Мельникова й до теперішнього часу залишаються фундаментальною базою досліджень для фахівців-гідробіологів.

У 1940-1941 рр. Г.Б. Мельников працює завідувачем кафедри дарвінізму Дніпропетровського держуніверситету та деканом біофаку держуніверситету. В евакуаціі, Г.Б. Мельников працював заступником директора і професором спочатку Сталінградського, а потім Бирського (Башкирія) педінститутів.

3 вересня 1944 р. Г.Б. Мельников очолив кафедру гідробіології й іхтіології в Дніпропетровському держуніверситеті, а 31951 р. до 1964 р. працював ректором Дніпропетровського університету. Г. Б. Мельников суттєво сприяв розвитку держуніверситету, організації підготовки спеціалістів за новими спеціальностями. У ці роки був створений фізико-технічний факультет, що став кузнею 3 підготовки кадрів у галузі космічної техніки й ракетобудування. 
Професором Г. Б. Мельниковим були опубліковані такі роботи: «Донные отложения Днепровского водохранилища» (1948) [5. с. 49-56], «Формирование фауны Днепровского водохранилища после восстановления плотины Днепрогэса» (1950), «Состав ихтиофауны и пути рыбохозяйственного освоения озера Ленина и малых водохранилищ Украины» (1955) [8. с. 32-49], «К проблеме формирования биологического режима в водохранилищах днепровского каскада» (1959), «К вопросу о классификации водохранилищ СССР» (1960), «Гидробиологическая и рыбохозяйственная характеристика малых рек северного Приазовья в связи с современным их состоянием» (1961).

У 1944-1947 pp. дніпропетровськими гідробіологами під керівництвом професора Г.Б. Мельникова були проведені унікальні дослідження «незапланованого експерименту» процесу повернення (після падіння рівня води, спричиненого руйнуванням під час війни греблі Дніпрогесу) сформованого стагнофільного гідробіологічного комплексу водосховища до первинного стану річкового реофільного комплексу. Зібрані, оброблені й узагальнені матеріали щодо результатів відновлення морфологічних та гідрологічних особливостей порожистої ділянки Дніпра, а також зміни флори i фауни в результаті катастрофічного падіння рівня води, були викладені в роботах Г.Б. Мельникова (1948) та в роботах, надрукованих у Віснику НДІ гідробіології, том 8. Г. Б. Мельников (1948) вважав, що катастрофічне падіння рівня води в Дніпровському водосховищі спричило відновлення умов порожистого Дніпра. На підставі досліджень 19441946 pp. було 3'ясовано, що порожиста ділянка Дніпра чітко розділилася на дві частини: 1-a - від м. Дніпропетровська до Таволжаного острову; 2-а - від Таволжаного острову до греблі Дніпрогесу (залишок водосховища). Перша частина характеризувалася великою швидкістю течії води, піщаним та кам'янистим дном, реофільною та потамофільною флорою та фауною; друга частина уповільненою течією води, мулистим дном та переважанням лімнофільної флори і фауни. Повного відновлення флори і фауни, характерних для колишньої порожистого Дніпра, не відбулося.

Враховуючи актуальність та необхідність забезпечення населення рибою, під керівництвом проф. Г.Б.Мельникова в травні 1950 року почали проводитися маршрутні іхтіологічні і гідробіологічні вивчення ставків Дніпропетровської області. В результаті проведених досліджень отриманий матеріал, який був опублікований у «Вестнике научно-исследовательского института гидробиологии. Том Х». Г.Б. Мельников опублікував у «Віснику» статтю «Гідробіологічна і рибогосподарська характеристика ставків степової зони України» в якій прийшов до наступних висновків:

1).Звільнити всі ставки від сорної риби або шляхом спеціальних методів знищення іiі, або, що можливо у ставках великих розмірів, шляхом запускання дорослих судаків, які будуть харчуватися за 
рахунок сорної риби. Але у такому випадку ставки повинні бути зарибленими годовиками коропу.

2). Звільнити ставки від тугорослого карася шляхом суцільного облову його або на зимовий період залишити ставки сухими для проморожування i таким чином звільнитися від шкідливих i непотрібних тварин і рослин.

3). Зарибити ставки культурними породами коропа.

4). Не допускати у нерестових і виросних ставках росту, а особливо гниття кінського щавеля, який підкислює воду і пригнічує розвиток зоопланктону, за рахунок якого годується молодь коропа.

5). Рибопитомникам слід вирощувати крупний вгодований зарибок культурного коропа.

6). Настійно рекомендувати однорічне ставкове коропове господарство.

7). Ставки, що заросли жорсткою водяною рослинністю, звільнити від останньої, так як ця рослинність наносить шкоду рибному господарство і збільшує загрозу розвитку личинок малярійного комара.

8). Науково-дослідному інституту гідробіології розгорнути роботи з підвищення природної кормової бази ставків шляхом введення нових видів кормових для риб тварин.

9). Дуже замулені ставки слід очищувати від мулу або у крайньому випадку проморожувати у зимовий час.

10). Нові ставки слід, по можливості, робити спускними.

У 1958 році Г.Б.Мельников опублікував монографію «Як вирощувати рибу в нагульних ставках» [14, 44 с], а в 1964 р., разом 3 О.М. Чапліною, «Поради колгоспним рибоводам» $[15,103 \mathrm{c}]$.

У подальших дослідженнях він приділяв значну увагу молоді риб середньої течії Дніпра (Кременчуг - Дніпродзержинськ), у зв'язку 3 умовами існування, біології та промисловій характеристиці риб середньої течії Дніпра у зв'язку з прогнозами рибного господарства Дніпродзержинського водосховища.

Уловлюючи тенденції розвитку науки у дослідженні космосу Г.Б. Мельников стає ініціатором і фактичним засновником принципово нового напрямку в гідробіологічній науці - космічної гідробіології. Як вчений-біолог професор Г.Б. Мельников, звернув свою увагу на проблему життєзабезпечення космонавтів в умовах тривалих космічних польотів (забезпечення екіпажу повітрям, водою, їжею, утилізація продуктів їх життєдіяльності), яка може бути оптимально вирішена шляхом створення замкнутої екологічної системи (ЗЕС). На думку Г.Б. Мельникова, для комплексного розв'язання проблем життєзабезпечення людини в умовах космічного польоту замкнута екологічна система має бути водною замкненою екологічною системою. В ній разом співіснуватимуть водна автотрофна і водна гетеротрофна ланки ЗЕС. Під час польоту космонавти будуть забезпечені і киснем для дихання (водна автотрофна ланка ЗЕС) і повноцінним харчуванням рибопродуктами (водна гетеротрофна ланка ЗЕС. 
У 1960 р. Г.Б. Мельникова було затверджено науковим керівником нового відділу космічної біології Інституту фізіології ім. акад. Богомольця АН УРСР. В 1961 році він ініціював створення в Дніпропетровському університеті, першої в Україні, лабораторії космічної гідробіології. Дніпропетровський університет став місцем заснування нового напрямку в гідробіології - космічна гідробіологія. Роботи лабораторії космічної гідробіології базувалися на використанні в якості можливих компонентів водної ЗЕС, таких водних організмів, як водорості, зоопланктери, кормові дріжджі, риби та ін.

Під керівництвом Г.Б. Мельникова була розроблена оригінальна методика вивчення дії екстремальних космічних факторів (космічного опромінення, невагомості тощо) на поведінку риб головного об'єкта «гетеротрофної ланки ЗЕС»; були проведені експериментальні роботи 3 вивчення поведінки риб в герметичних акваріумах, а також 3 вивчення раціонів харчування риб на основі хлорели. В 1965 році у своїй доповіді на I з’їзі Всесоюзного гідробіологічного товариства організатор та науковий керівник робіт професор Г.Б. Мельников сформулював проблематику, методологію та завдання космічного рибництва і шляхи його подальшого розвитку.

Мельников Г.Б. підготував більш ніж 30 кандидатів наук, був науковим консультантом багатьох докторських дисертацій. Він нагороджений орденом Трудового Червоного Прапора, орденом «Знак Пошани», трьома медалями, удостоєний почесного звання Заслуженого діяча науки, був Почесним членом ВГБО, членом Іхтіологічної комісії СРСР, членом редколегії «Гідробіологічного журналу».

\section{ВЫДАЮЩИЙСЯ УКРАИНСКИЙ УЧЕНЫЙ В ОБЛАСТИ ВОДНЫХ БИОРЕСУРСОВ И АКВАКУЛЬТУРЫ, ОСНОВАТЕЛЬ КОСМИЧЕСКОЙ ГИДРОБИОЛОГИИ ПРОФЕССОР Г.Б. МЕЛЬНИКОВ}

\section{К 115-летию со дня рождения}

Дворецкий А.И. - д. биол. н., профессор, dvoretsk@list.ru

Байдак Л.A. - к.ист. н., с.н.c., lbajdak@i.ua

Днепровский государственный аграрно-экономический университет

Рассмотрена жизнь и деятельность выдающегося украинского ученого в области водных биоресурсов и аквакультуры, основателя космической гидробиологии профессора Г.Б.Мельникова. Отмечен вклад проф. Г.Б.Мельникова в формирование учения о техногенной трансформации пресноводных экосистем. По широте охвата материала, глубине его обработки, практической значимости выводов работы Г. Б. Мельникова и до настоящего времени остаются фундаментальной базой исследований для специалистов-гидробиологов.

Подчеркнута роль Г.Б.Мельникова в основание нового направления гидробиологической науки - космической гидробиологии. Улавливая тенденции развития науки в исследовании космоса Б. Мельников становится инициатором и фактическим основателем принципиально нового направления 
в гидробиологической науке - космической гидробиологии. Как ученыйбиолог профессор Г. Б. Мельников, обратил свое внимание на проблему жизнеобеспечения космонавтов в условиях длительных космических полетов (обеспечение экипажа воздухом, водой, пищей, утилизация продуктов их жизнедеятельности), которая может быть оптимально решена путем создания замкнутой экологической системы (ЗЕС ). Под руководством Б. Мельникова была разработана оригинальная методика изучения действия экстремальных космических факторов (космического облучения, невесомости и т.п.) на поведение рыб - главного объекта «гетеротрофного звена ЗЕС»; были проведены экспериментальные работы по изучению поведения рыб в герметичных аквариумах, а также по изучению рационов питания рыб на основе хлореллы.

Мельников Б. подготовил более 30 кандидатов наук, был научным консультантом многих докторских диссертаций. Он награжден орденом Трудового Красного Знамени, орденом «Знак Почета», тремя медалями, удостоен почетного звания Заслуженного деятеля науки, был Почетным членом ВГБО, членом ихтиологические комиссии СССР, членом редколлегии «Гидробиологического журнала».

Ключевые слова: гидроэкология, техногенно трансформированные пресноводные экосистемы, Днепрогэс, Днепропетровская государственная гидробиологическая станция, водохранилище, зоопланктон, космическая гидробиология, ихтиология.

\title{
PROFESSOR G. B. MELNIKOV - OUTSTANDING UKRAINIAN SCIENTIST IN THE RANGE AQUATIC BIORESOURCES AND AQUACULTURE, THE FOUNDER OF SPACE HYDROBIOLOGY
}

\author{
To the 115th anniversary of the birth
}

\author{
A.I. Dvoretsky - Doctor of Biology, Profesor, dvoretsk@list.ru \\ L.A. Bajdak - PhD in History, Senior Scientific Officer, lbajdak@i.ua \\ Dniprovsk State Agrarian and Economic University
}

The life and work of the outstanding Ukrainian scientist in the range of aquatic bioresources and aquaculture, Professor G.B. Melnikov which was the founder of space hydrobiology are reviewed. We stress the importance of the the founder of space hydrobiology contribution of prof. G.B. Melnikov in the process of founding of the theory of man-made transformation of freshwater ecosystems. By the breadth of the material coverage, the depth of its processing, the practical significance of the conclusions of the work of G. B. Melnikov, to this day remain the fundamental research base for hydrobiologists.

It was also emphasized the role of prof. G.B. Melnikov in the creation of a new direction in hydrobiological science - space hydrobiology. Catching the development trends of science in space exploration B. Melnikov has become the initiator and actual founder of a fundamentally new direction in hydrobiological science - space hydrobiology. As a biologist, professor G. B. Melnikov, turned his attention to the problem of life support for astronauts in long-term space missions (providing crew with air, water, food, utilization of their waste products), which can be optimally solved by creating a closed ecological system (WEU ) Under the leadership of B. Melnikov, an original methodology was developed to study the effect of extreme cosmic factors (cosmic radiation, weightlessness, etc.) on the behavior of fish - the main object of the "WEU heterotrophic link"; experimental 
work was carried out to study the behavior of fish in sealed aquariums, as well as to study the diets of fish based on chlorella.

Melnikov G.B. has prepared more than $30 \mathrm{PhDs}$, has been a scientific advisor to many doctoral theses. He was awarded the Order of the Red Banner of Labor, the Order of the Badge of Honor, three medals, was awarded the honorary title of Honored Worker of Science, was an Honorary Member of the All-Russian State Security Organization, Member of the Ichthyological Commission of the USSR, Member of the Editorial Board of the Hydrobiological Journal.

Key words: hydroecology, technologically transformed freshwater ecosystems, Dneproges, Dnipropetrovsk State Hydrobiological Station, reservoir, zooplankton, space hydrobiology, ichthyology.

\section{ЛІТЕРАТУРА}

1. Байдак Л.А., Дворецькій А.І. Техногенно трансформовані прісноводні екосистеми. Монографія. Дніпро: Ліра. 2017. 207 с

2. Рева А.Д. История биолого-технологического факультета Днепропетров-ского государственного университета. Днепропетровск, 1998.

3. Справка об организации института и развитии научных направлений. [Рукопись]. Бібліотека НДІ біології ДНУ ім. О. Гончара. 43 с.

4. Мельніков Г.Б. Зоопланктон порожистої дільніці р. Дніпра та його зміни під вплівом побудування греблі Дніпростану. Під ред. проф. Д.О. Свіренка. Віснік Дніпропетровської гідробіологічної станиії. T. II. Дніпропетровськ: Дніпропетровська друкарня школі ФЗУ ім. Косарева, 1937. С. 76-84.

5. Мельников Г.Б. Калитаева Л.С. Донные иловые отложения Днепровского водохранилища. Вестник научно-исследовательского института гидробиологии. Авторефераты. T. VIII. Днепропетровск: Типография завода им. Петровского, 1948. С. 49-56.

6. Мельников Г.Б. Гидробиологические изменения порожистой части р. Днепра в связи с разрушением плотины Днепрогес. Вестник научноисследовательского института гидробиологии. Авторефераты. T. VIII. Днепропетровск: Типография завода им. Петровского, 1948. C. 79-90.

7. Мельников Г.Б. Ихтиофауна озера Ленина (Днепровского водохранилища) после его восстановления. Вестник научноисследовательского института гидробиологии. Т. ХІ. К.: Изд-во КГУ им. Т.Г. Шевченко, 1955. С. 163-188.

8. Мельников Г.Б. Состав ихтиофауны и пути рыбохозяйственного освоения озера Ленина и малых водохранилищ Украины. Bonpocbl ихтиологии. 1955. Вып. 3. С. 32-49.

9. Мельников Г.Б. К вопросу о классификации водохранилищ СССР. Труды зонального совещания по типологии и биологическому обоснованию рыбохозяйственного использования внутренних 
(пресноводных) водоемов южной зоны СССР. Кишинев: Штиинца, 1962. С. $155-160$.

10. Мельников Г.Б., Булахов В. Л. К вопросу о направленном формировании фауны рыб озера имени Ленина. Труды зонального совещания по типологии и биологическому обоснованию рыбохозяйственного использования внутренних (пресноводных) водоемов южной зоны СССР. Кишинев: Штиинца, 1962. С. 320-323.

11. Мельников Г.Б. Задачи гидробиологии в связи с освоением космического пространства. Вопросы гидробиологии. М., 1965. C. 283-285.

12. Мельников Г.Б. Закономерности формирования и становления зоопланктона в водохранилищах СССР. Гидробиологический журнал. 1966. T. II. № 2. C. 58-64.

13. Мельников Г.Б. Итоги развития пресноводной гидробиологии на Украине за 50 лет. Биологическая наука в университетах и педагогических институтах Украины за 50 лет: материалы межвуз. республ. конф. Харьков, 1968. С. 198-202.

14. Мельников Г.Б. Як вирощувати рибу в нагульних ставках. Дніпропетровське обласне видавництво. 1958. 44 с.

15. Мельников Г.Б., Чапліна О.М. Поради колгоспним рибоводам. Дніпропетровськ: Промінь. 1964. 103 с.

\section{REFERENSES}

1. Bajdak L.A., Dvorec'kij A.I. (2017). Tekhnogenno transformovani prisnovodni ekosistemi. Monografiya. Dnipro: Lira. [in Ukrainian].

2. Reva A.D. (1998). Istoriya biologo-ehkologicheskogo fakul'teta Dnepropetrovskogo gosudarstvennogo universiteta. [in Russian].

3. Spravka ob organizacii instituta i razvitii nauchnyh napravlenij. Dnepropetrovsk. [Rukopis]. Biblioteka NDI biologii DNU im. O. Gonchara. [in Russian].

4. Mel'nikov G.B. (1937). Zooplankton porozhistoï dil'nici r. Dnipra ta jogo zmini pid vplivom pobuduvannya grebli Dniprel'stanu. Visnik Dnipropetrovs'koï Gidrobiologichnoï Stanciï. T. II. Dnipropetrovs'k: Dnipropetrovs'ka drukarnya shkoli FZU im. Kosareva. P. 76-84. [in Ukrainian].

5. Mel'nikov G.B., Kalitaeva L.S., EH. L. Bro (1948). Donnye ilovye otlozheniya Dneprovskogo vodohranilishcha. Vestnik nauchnoissledovatel'skogo instituta gidrobiologii. Avtoreferaty. T. VIII. Dnipropetrovs'k: Tipografiya zavoda im. Petrovskogo. P. 49-56. [in Russian].

6. Mel'nikov G.B. (1948). Gidrobiologicheskie izmeneniya porozhistoj chasti r. Dnepra v svyazi s razrusheniem plotiny Dneprogehs. Vestnik nauchno-issledovatel'skogo instituta gidrobiologii. Avtoreferaty. 
T. VIII. Dnipropetrovs'k: Tipografiya zavoda im. Petrovskogo. P. 79-90. [in Russian].

7. Mel'nikov G.B. Ihtiofauna ozera Lenina (Dneprovskogo vodohranilishcha) posle ego vosstanovleniya (1955). Vestnik nauchnoissledovatel'skogo instituta gidrobiologii. T. XI. Kyiv: Izd-vo KGU im. T.G. SHevchenko. P. 163-188. [in Russian].

8. Mel'nikov G.B. (1955). Sostav ihtiofauny i puti rybohozyajstvennogo osvoeniya ozera Lenina i malyh vodohranilishch Ukrainy. Voprosy ihtiologii. no.3. P. 32-49. [in Russian].

9. Mel'nikov G.B. (1962). K voprosu o klassifikacii vodohranilishch SSSR. Tr. Zonal'n. soveshch. po tipologii i biol. obosnovaniyu rybohoz. ispol'zovaniya vnutrennih (presnovod.) vodoemov yuzhnoj zony SSSR. Kishinev: SHtiinca. P. 155-160. [in Russian].

10. Mel'nikov G.B., Bulahov V.L. (1962). K voprosu o napravlennom formirovanii fauny ryb ozera imeni Lenina. Tr. Zonal'n. soveshch. po tipologii i biol. obosnovaniyu rybohoz. ispol'zovaniya vnutrennih (presnovod.) vodoemov yuzhnoj zony SSSR. Kishinev: SHtiinca. P. 320-323. [in Russian].

11. Mel'nikov G.B. (1965). Zadachi gidrobiologii v svyazi s osvoeniem kosmicheskogo prostranstva. Voprosy gidrobiologii. Moscow. P. 283285. [in Russian].

12. Mel'nikov G.B. (1966). Zakonomernosti formirovaniya i stanovleniya zooplanktona v vodohranilishchah SSSR. Gidrobiologicheskij zhurnal. Vol. II. no. 2. P. 58-64. [in Russian].

13. Mel'nikov G.B. (1968). Itogi razvitiya presnovodnoj gidrobiologii na Ukraine za 50 let. Biologicheskaya nauka v universitetah i pedagogicheskih institutah Ukrainy za 50 let: materialy mezhvuz. respubl. konf. Har'kov. P. 198-202. [in Russian].

14. Mel'nikov G.B. (1958). YAk viroshchuvati ribu v nagul'nih stavkah. Dnipropetrovs'k: Dnipropetrovs'ke oblasne vidavnictvo. [in Ukrainian].

15. Mel'nikov G.B., Chaplina O.M. (1964). Poradi kolgospnim ribovodam. Dnipropetrovs'k: Promin'. [in Ukrainian]. 